\title{
Walczyć czy odstąpić? Postawy i dylematy oficerów Obszarów Warownych ,Grodno" i „Wilno" we wrześniu 1939 roku
}

Streszczenie. W sierpniu 1939 r. wszystkie jednostki Wojska Polskiego stacjonujące w Grodnie i w Wilnie zostały zmobilizowane do walki z Niemcami i odesłane na granicę zachodnią. W ten sposób oba miasta zostały pozbawione regularnych oddziałów wojska i stały się bezbronne w obliczu najazdu sowieckiego. W tej sytuacji walka i obrona obu miast skazana była na niepowodzenie, a ewakuacja na Litwę była jedynym możliwym wyjściem dla pozostałych w Grodnie i Wilnie jednostek wojska. Wielu oficerów Obszarów Warownych „Grodno” i Wilno” musiało dokonać trudnego wyboru, co niejednokrotnie wpłynęło na ich postawę w tym trudnym czasie.

Słowa kluczowe: wrzesień 1939, Obszar Warowny, Grodno, Wilno, Wojsko Polskie, ewakuacja.

$\mathrm{P}$ ytanie zawarte w tytule należy do gatunku tych, które od lat nie może doczekać się jednoznacznej odpowiedzi. Równie trudna wydaje się też zdecydowana ocena postaw ludzi, którzy w obliczu dramatycznych wydarzeń wojny 1939 r. zmuszeni byli podejmować decyzje. Dyskusje na te tematy odżywają prawie każdego roku przy okazji wspomnień o bohaterskiej, ale nierównej walce Polaków. Szczególne emocje wzbudza sprawa agresji ZSRR na wschodnie tereny Drugiej Rzeczpospolitej. Wtedy też powraca pytanie, dlaczego tak duże i znaczące dla Polaków miasta - Grodno i Wilno nie przystąpiły do obrony. Czy podjęcie walki rzeczywiście było wówczas niemożliwe i pozbawione sensu, zwłaszcza że mimo niezwykle trudnej sytuacji militarnej Polski w tym czasie Polacy wykazali się ogromną determinacją - jako pierwsi w Europie stawili zbrojny opór hitlerowskim Niemcom, gotowi także walczyć z najazdem sowieckim.

Wojna stała się sprawdzianem dla całego społeczeństwa, w tym wojska, ale obok gotowości do walki w wielu przypadkach ujawniła także postawy i charaktery,

\footnotetext{
*E-mail: a.jedrzejewska@muzeumtradycji.pl.
} 
które zmieniły dotychczasowe opinie, zwłaszcza na temat wielu dowódców. W sytuacjach zagrożenia dały znać o sobie słabości, rozterki dodatkowo pogłębiane przez skomplikowane okoliczności - złą łączność, nieprecyzyjne i mało stanowcze rozkazy, chaos organizacyjny, a wszystko to na tle dynamicznie rozwijającej się sytuacji wojennej. Plany obrony opracowane na wypadek wojny z Niemcami, w obliczu najazdu 17 września, okazały się zawodne. Przygraniczne garnizony, tuż przed wybuchem wojny pozbawione w wielu wypadkach jednostek regularnego wojska, nie były w stanie sprostać tej napaści. Taka sytuacja miała miejsce m.in. w Okręgu Korpusu nr III, który był jednym z największych w Drugiej Rzeczpospolitej. Terytorialnie obejmował województwa: białostockie, wileńskie i część nowogródzkiego. Na jego obszarze stacjonowały wielkie jednostki: trzy dywizje piechoty (dalej: DP) (1, 19 i 29), trzy brygady kawalerii (Wileńska, Podlaska i Suwalska), trzy pułki artylerii lekkiej oraz inne jednostki i instytucje wojskowe. Oba miasta: Grodno i Wilno były w Drugiej Rzeczpospolitej silnymi i dobrze uzbrojonymi garnizonami. W Grodnie stacjonowała 29 Dywizja Piechoty i dwa z trzech pułków wchodzących w jej skład: 81 Pułk Strzelców Grodzieńskich im. Króla Stefana Batorego oraz 76 Lidzki Pułk Piechoty im. Ludwika Narbutta. Ponadto w mieście dyslokowane były: 29 pal (bez 1 dywizjonu w Suwałkach) i 7 Batalion Pancerny. Miały tu także swoją siedzibę dowództwa: Okręgu Korpusu (dalej: OK) nr III, 29 DP i 3 Grupy Artylerii. Natomiast w Wilnie stacjonowały wszystkie jednostki 1 Dywizji Piechoty Legionów (dalej: DPLeg.): 1, 5 i 6 pułk piechoty (dalej: pp), 1 pal oraz 4 Pułk Ułanów Zaniemeńskich. Mieściło się tu także dowództwo Wileńskiej Brygady Kawalerii.

Wiosną 1939 r. sytuacja militarna obu miast się zmieniła. Wówczas najbardziej wartościowe pod względem bojowym i najlepiej wyposażone jednostki wileńskie i grodzieńskie otrzymały przydziały mobilizacyjne z przeznaczeniem do walki z Niemcami w znacznej odległości od macierzystych garnizonów. I tak 1 DPLeg. weszła w skład Grupy Operacyjnej „Wyszków”, będącej odwodem Naczelnego Wodza, natomiast wspomniana 29 DP i Wileńska Brygada Kawalerii zostały zmobilizowane do odwodowej Armii „Prusy” dowodzonej przez gen. bryg. Stefana Dęba-Biernackiego. Dodatkowo do wszystkich trzech brygad kawalerii z obszaru OK nr III zmobilizowane zostały także trzy dywizjony pancerne ze składu 7 Batalionu Pancernego z Grodna.

W pierwszych dniach września 1939 r. jednostki grodzieńskie i wileńskie wyładowane zostały z transportów kolejowych w takich miejscowościach, jak: Ostrów Mazowiecka (1, 5 i 6 pp), Skierniewice (76 pp), Radziwiłłów (81 pp), Koluszki (4 Pułk Ułanów Zaniemeńskich)1. Odesłanie tych oddziałów w głąb kraju oznaczało, że oba miasta Grodno i Wilno zostały pozbawione regularnego wojska i w praktyce stały się bezbronne. Wprawdzie jeszcze wiosną $1939 \mathrm{r}$.

${ }^{1}$ J. Wróblews ki, Armia „Prusy”1939, Warszawa 1986, s. 47-48; A. Wodzyń ski, 1 Dywizja Piechoty Legionów, Warszawa 2016, s. 17, 43. 
przystąpiono do tworzenia Zgrupowania „Grodno”, ale jego zadaniem - na wypadek wojny - miała być osłona wschodniego skrzydła Samodzielnej Grupy Operacyjnej „Narew” oraz obrona obszaru wzdłuż granicy z Prusami Wschodnimi. Dowódcą Zgrupowania został gen. bryg. Józef Olszyna-Wilczyński.

Także pod koniec sierpnia 1939 r., na bazie Zgrupowania Dowódcy OK nr III, utworzona została Grupa Operacyjna (dalej: GO) „Grodno”. W pracach nad jej organizacją uczestniczyli: gen. J. Olszyna-Wilczyński, ppłk dypl. Wilhelm Kasprzykiewicz (kierownik Samodzielnego Referatu Ogólnego DOK nr III) i płk Ignacy Oziewicz (dowódca 29 DP). W skład GO „Grodno” weszły także wraz z odrębnymi dowództwami: Obszar Warowny „Grodno” i Obszar Warowny „Wilno”. Jak wspominał po latach płk B. Hulewicz, plan mobilizacyjny przewidywał użycie w tym celu tylko dziewięciu kompanii wartowniczych oraz dwóch kompanii asystencyjnych. Konieczna więc była mobilizacja rezerwistów, na co wyraził zgodę gen. J. Olszyna-Wilczyński. W składzie dowództwa Obszaru Warownego (dalej: OW) „Grodno" znaleźli się m.in. mjr Karol Miałkowski (jako szef sztabu), mjr Tadeusz Styczyński (szef fortyfikacji Grodno), mjr st. spocz. Stanisław Kobyliński (kwatermistrz i szef wszystkich służb), kpt. Marian Zywert (szef oddziału I), mjr Roman Banaszak (szef łączności). Jednak w momencie wybuchu wojny GO „Grodno” pozostawała w stadium organizacji. Jak twierdził jej szef sztabu: ,[...] sprawy natury organizacyjnej, personalnej, materiałowej były w planie nietknięte i trzeba było uciekać się z konieczności do improwizacji”2. Zatem w praktyce grupa ta nie zaistniała.

Grodno i Wilno stanęły przed problemem obrony, mając do dyspozycji niewystarczające siły. W sprawie Grodna zdecydowano o pozostawieniu w mieście władz administracyjnych oraz obsadę granicy litewskiej i sowieckiej. Ponadto miały pozostać tu także „oddziały bezpośredniej obrony Grodna, które nie przedstawiają większej wartości”’3. W rezultacie miasto było bezbronne. Oprócz władz administracyjnych znajdowała się tu jedynie niewielka załoga złożona $\mathrm{z}$ dwóch batalionów sformowanych w Ośrodku Zapasowym 29 DP, pięć plutonów artylerii pozycyjnej oraz oddział ochotników pod dowództwem mjr. Benedykta Serafina. Jednostka ta przeszła do historii jako batalion wartowniczy $\mathrm{nr} 31^{4}$.

Mimo fatalnej sytuacji, w tym niedostatecznego uzbrojenia, gotowość była ogromna. Jednak w sprawie organizacji obrony miasta nastąpił rozdźwięk - po jednej stronie stanęły władze administracyjne, które nie przejawiały chęci do jakichkolwiek działań, po drugiej znajdowali się mieszkańcy, głównie młodzież, gotowi na daleko idące poświęcenia i na walkę za wszelką cenę. Po wyjeździe

2 Sprawozdanie mjr. Karola Miałkowskiego z prac organizacyjnych „Grupy Grodno” stworzonej z rozkazu Naczelnego Wodza 1 IX 1939 r., Instytut Polski i Muzeum im. Gen. Sikorskiego w Londynie [dalej: IPMS], sygn.B.I.70.D, karty bez paginacji.

${ }^{3}$ Polskie Sity Zbrojne $w$ drugiej wojnie światowej, t. I (Kampania wrześniowa 1939), cz. 3 (Przebieg działań od 9 do 14 września), Londyn 1959, s. 611.

${ }^{4}$ Ibidem, s. 82. 
płk. B. Hulewicza 12 września do Pińska, jego miejsce na stanowisku dowódcy OW „Grodno” zajął płk w st. spocz. Bronisław Adamowicz. On także nie przejawiał zainteresowania obroną, a bardziej ewakuacją na Litwę, zgodnie z rozkazem gen. J. Olszyny-Wilczyńskiego. Sceptycznie też podchodził do możliwości skutecznych działań.

Równie otwarta, tak jak w przypadku Grodna, pozostawała sprawa obrony Wilna. Sytuacja obu miast była podobna i tak samo trudna. Zgodnie z rozkazem, który nadszedł 9 września z kwatery Naczelnego Wodza, w Wilnie pozostać miał tylko mały garnizon $w$ sile dwóch lub trzech kompanii piechoty oraz administracja cywilna ${ }^{5}$. W rezultacie pozostały tu także ośrodki zapasowe złożone z rezerwistów, bardzo źle wyposażone, gdyż jak wspomniano, także garnizon wileński przed wybuchem wojny został pozbawiony regularnych jednostek wojska. Dowódcą Obszaru Warownego „Wilno” od 12 września był ppłk Tadeusz Podwysocki, który był wówczas także komendantem garnizonu wileńskiego. Słabo wprowadzony w sprawy Obszaru Warownego, miał opinię oficera nieodznaczającego się szczególną inwencją i talentem organizacyjnym w sytuacjach trudnych ${ }^{6}$. Podjął jednak pewne działania, często prosząc o radę innych oficerów, co potwierdził płk Kazimierz Rybicki z Dowództwa OK nr III ${ }^{7}$. W dniu 14 września 1939 r. w Wilnie została utworzona ekspozytura DOK nr III, przeniesiona z Grodna. W jej składzie znalazła się część oficerów sztabu, a na jej czele stanął płk dypl. Jarosław Okulicz-Kozaryn, dotychczasowy dowódca OPL OK nr III. On również skłonny był podjąć walkę w obronie miasta, gdyż jak podkreślił w rozmowie juzowej z gen. J. Olszyną-Wilczyńskim: „,...] Chciałbym tą obroną zaznaczyć tylko [...] pewien protest przed siłą zajmowania tego co nasze, żeby nie było tego, że oddajemy zupełnie bez walki"».

Pogląd ten podzielał także ppłk Kazimierz Kardaszewicz, dowódca pułku Korpusu Ochrony Pogranicza (dalej: KOP) „Wilno” i granicznego odcinka litewskiego. Na stanowisko to został powołany 26 sierpnia 1939 r., natomiast w momencie wybuchu wojny dobrowolnie podporządkował się dowództwu Obszaru Warownego „Wilno”. Jak zauważył, we wrześniu „w Komendzie Obszaru Warownego, tak również $\mathrm{w}$ terenie przygotowania [do] obrony były prowadzone bez przekonania"9. Mimo to zamierzał zebrać podległe mu baony (,Niemenczyn”, „Troki”, „Nowe Święciany”, „Orany”) blisko Wilna, by wykorzystać je do

\footnotetext{
5 Ibidem, s. 548.
}

${ }^{6}$ Opinia inspektora armii gen. M. Norwid-Neugebauera o ppłk. T. Podwysockim, 18 III 1936, Instytut Józefa Piłsudskiego w Nowym Jorku [dalej: IJPNY], Archiwum Józefa Piłsudskiego [dalej: AJP], sygn. 701/1/120, www. pilsudski.org./archiwa/ (dostęp: 4 VI 2018).

${ }^{7}$ Relacja pulkownika Kazimierza Rybickiego z wydarzeń w Wilnie i na pograniczu polsko-litewskim, [w:] Wrzesień 1939 na Kresach w relacjach, wybór i oprac. C.K. Grzelak, Warszawa 1999, s. 152.

${ }^{8}$ Cyt. za: C. Grzelak, Kresy w czerwieni. Agresja Związku Radzieckiego na Polskę w 1939 roku, Warszawa 2001, s. 261.

${ }^{9}$ Relacja podpułkownika piechoty Kazimierza Kardaszewicza, dowódcy putku KOP „Wilno” (jednocześnie dowódcy granicznego odcinka litewskiego), [w:] Wrzesień 1939 na Kresach..., s. 82. 
obrony miasta. Część z nich miała walczyć także w obronie Grodna, m.in. baon „Troki” uzupełniony siłami baonu „Nowe Święciany” ${ }^{\circ}$.

Brakowało broni dla wszystkich zmobilizowanych rezerwistów oraz dla ochotników - młodzieży przeszkolonej w ramach Przysposobienia Wojskowego. Według wyliczeń Czesława Grzelaka w momencie najazdu sowieckiego Dowództwo Obszaru Warownego „Wilno” dysponowało 14000 ludzi, z czego tylko około 6500 posiadało broń ${ }^{11}$. Los Wilna był zatem bardzo niepewny, ale płk J. Okulicz-Kozaryn poczynił przygotowania do obrony, wykorzystując siły i środki, jakie wówczas posiadał. Podobnie jak ppłk T. Podwysocki miał świadomość, że walka będzie mało efektywna. Jej celem miało być zatrzymanie pierwszego uderzenia wojsk sowieckich i umożliwienie ewakuacji urzędów, wojska, ewentualnie ludności cywilnej ${ }^{12}$. Plan ten nie przewidywał zatem stawienia twardego oporu i obrony tak długo, jak będzie to możliwe. Miał on znaczenie bardziej moralne niż praktyczne. Entuzjazm i wzrost uczuć patriotycznych nie był jednak w stanie wypełnić braków w uzbrojeniu i w wyposażeniu wszystkich zmobilizowanych do ewentualnej walki. Pogarszająca się sytuacja i postęp wojsk sowieckich spowodowały, że zamiary płk. J. Okulicza-Kozaryna i ppłk. T. Podwysockiego stawienia oporu stały się nierealne.

Nie powiodły się także plany ppłk. K. Kardaszewicza. Jego siły, rozbite i rozproszone po zajęciu Wilna i Grodna przez siły sowieckie, zaczęły się przemieszczać w stronę granicy litewskiej, by przekroczyć ją w m.in. w miejscowości Kalety. Mimo ogromnej woli walki oraz licznych prób jej podjęcia w różnych miejscach po opuszczeniu Wilna, ppłk K. Kardaszewicz zmuszony był również przekroczyć granicę.

Myśl o odwrocie na Litwę była ciągle obecna w działaniach dowództwa Obszaru Warownego „Wilno”. Pod wieczór 18 września płk J. Okulicz-Kozaryn odstąpił od swego wcześniejszego zamiaru stawienia oporu i zgodnie z rozkazem gen. J. Olszyny-Wilczyńskiego nakazał natychmiastowe wycofanie w kierunku granicy litewskiej. Kierunki ewakuacji zostały określone dla poszczególnych ugrupowań. Jak podaje szef sztabu Obszaru Warownego „Wilno”, mjr dypl. Aleksander Marian Romiszowski, porządek ewakuacji był następujący: „[...] - ośrodek zapasowy 1.DP [Leg.] szosą na Mejszagołę, - ośrodek zapasowy brygady kawalerii - traktem na Suderwę, - ośrodek zapasowy artylerii lekkiej i stacja zborna z Landwarowa przez Zawiasy, - baon wartowniczy i baon Obrony Narodowej przez Troki, - trzy baony KOP miały odejść ostatnie jako straż tylna na Troki i Zawiasy"13.

${ }^{10}$ Szerzej: ibidem, s. 83-89.

${ }^{11}$ C. Grzelak, Wilno-Grodno-Kodziowce 1939, Warszawa 2002, s. 66.

12 Ibidem.

${ }^{13}$ Relacja szefa sztabu Dowództwa Obszaru Warownego Wilno, majora dyplomowanego Aleksandra Mariana Romiszowskiego z wydarzeń w Wilnie, Paryż 12 października 1939 r., [w:] Wrzesień 1939 na Kresach..., s. 150-151. 
Rozkaz o opuszczeniu Wilna wywołał naturalnie konflikt wśród potencjalnych obrońców i ujawnił różnice poglądów. Wielu oficerów musiało dokonać wyboru między własnym sumieniem, poczuciem realizmu a obowiązkiem wykonania rozkazu o ewakuacji. Wszystko to powodowało, że często pod adresem wyższych dowódców padały oskarżenia o zdradę, dochodziło także do samobójstw niektórych oficerów, którzy nie mogli i nie chcieli pogodzić się z koniecznością oddania miasta bez walki. Pełną emocji atmosferę w tym dniu, 18 września, przedstawił m.in. płk Kazimierz Rybicki: „[...] O godz. 10.00 przybyli do Obozu Warownego dcy pododcinków północy i wschodu, ppłk Pawlik i ppłk. kaw. Grad-Soniński [...]. W rozmowie z ppłk. Pawlikiem, dcą ośrodka Zapasowego 1.DP Leg., a obecnie dcą odcinka północnego oraz ppłk. Grad-Sonińskim i Obtułowiczem wyczułem ich załamanie się duchowe oraz pesymizm w sprawie obrony. Krótka odprawa, żywym słowem przełamałem ich duchowy stan i serca wzniosły się do góry. Jednomyślnie uznali słuszność moich koncepcji o nieustępliwej obronie i że bronić się możemy skutecznie dobrych kilkanaście dni. Wszedł ppłk Podwysocki z pisemnym rozkazem dcy III Korpusu, że Wilna bronić nie będziemy, wojny z Sowietami nie prowadzimy, w wypadku silnego nacisku odchodzić mamy z orężem na teren Litwy Kowieńskiej. Był to grom z jasnego nieba, obecni oficerowie z pogardą i wrzaskiem »to zdrada « opuścili natychmiast Obóz Warowny"14.

Nie sposób scharakteryzować postawy wszystkich oficerów Obszarów Warownych „Grodno" i „Wilno”, którzy we wrześniu 1939 r. zmuszeni byli podejmować trudne decyzje. Można natomiast wyróżnić typy pewnych zachowań i cechy charakteru, które w szczególny sposób ujawniły się właśnie wtedy. Były to z pewnością: dezorientacja, zwątpienie, ale także ostrożność i chłodna kalkulacja, opanowanie i konsekwencja w podejmowaniu decyzji, determinacja, albo wręcz brawura, w końcu bezsilność i rozpacz.

Dezorientacja dotyczyła wszystkich. Zła łączność, zmieniające się rozkazy nie sprzyjały przemyślanym decyzjom. Ponadto atmosfera zagrożenia u wielu oficerów wyzwoliła instynkty, które stanowiły przeciwieństwo dotychczasowych opinii i ocen. Płk Adam Obtułowicz i ppłk Józef Grad-Soniński przeżyli chwile zwątpienia i rezygnacji, wynikające niewątpliwie z realnej oceny sytuacji i możliwości skutecznej obrony. Na zmianę ich postawy wpłynął dopiero płk Rybicki, który podobnie jak wielu innych doświadczył uczucia goryczy i zwątpienia.

Rezygnacja i zobojętnienie, a wręcz bezradność, stały się udziałem gen. Józefa Olszyny-Wilczyńskiego. To najbardziej tragiczna postać września 1939 r. na Grodzieńszczyźnie. Mimo doświadczeń bojowych z lat 1914-1921, wielokrotnych odznaczeń za męstwo i odwagę, w obliczu najazdu sowieckiego stracił kontrolę nad sytuacją, która wyraźnie go przerosła. Do dziś obarczany jest winą za tragedię Grodna, za odstąpienie od obrony Wilna, za postawę pełną zwątpienia i niezdecydowania.

${ }^{14}$ Relacja putkownika Kazimierza Rybickiego z wydarzeń Wilnie i na pograniczu litewskim, 23 października 1939 roku, [w:] ibidem, s. 159. 
Z pewnością opanowanie i konsekwencję w działaniu można dostrzec u płk. Jarosława Okulicz-Kozaryna. W opinii swych przełożonych uchodził za oficera obdarzonego tymi właśnie cechami. W 1938 r. gen. dyw. Juliusz Rómmel, Inspektor Armii w swej opinii stwierdził nawet, że płk J. Okulicz-Kozaryn „,nie przejmuje się trudnościami - zawsze spokojny, pewny dowódca na wojnie"15. Jednak nie sprostał sytuacji zaistniałej w Wilnie. Zgodnie z otrzymanym rozkazem opuścił miasto. Przekroczył granicę litewską, gdzie został internowany.

Ostrożność w działaniu charakteryzowała natomiast płk. Benedykta Chłusewicza, szefa sztabu DOK III. Oficer ten wyraźnie kierował się troską o własne życie, z czego był znany już w latach wcześniejszych. Przykładowo w 1935 r. płk Józef Werobej, dowódca Piechoty Dywizyjnej 13 DP orzekł, że płk dypl. B. Chłusewicz jest ,[...] Bardzo powolny w postępowaniu i powzięciu decyzji. Mało skłonny do ryzyka"16. W tym samym roku dowódca 13 DP, płk. dypl. Aleksander Myszkowski ocenił, że w warunkach bojowych płk. dypl. B. Chłusewicza cechuje „ostrożność i niechęć do wikłania się w niebezpieczne bądź względnie trudne położenie"17. Z pewnością ostrożność zdecydowała, że pułkownik opuścił w tajemnicy swego przełożonego, gen. J. Olszynę-Wilczyńskiego, który z kolei do ostatniej chwili zwlekał z wyjazdem z Sopoćkiń koło Grodna.

Nominowany w sierpniu 1939 r. na stanowisko szefa sztabu Obszaru Warownego „Grodno”, mjr Karol Miałkowski także przekroczył granicę litewską. Uprzedzony o sowieckim niebezpieczeństwie, opuścił Teolin, gdzie przebywał gen. J. Olszyna-Wilczyński ze swoim sztabem. Nieznane są refleksje mjr. K. Miałkowskiego na temat jego decyzji o opuszczeniu kraju, ale pozostała relacja dotycząca przebiegu wydarzeń 22 września z udziałem ppłk. B. Chłusewicza, spisana 22 kwietnia 1940 r. w Kalwarii Suwalskiej. W obszernym fragmencie na ten temat mjr K. Miałkowski stwierdził m.in.: „Wyjechałem natychmiast z kpt. Serdułą Michałem z szef [ostwa] Inż.[ynierii] OK III i ppor rez. Sławińskim na szosę Sonicze-Giby-Kopciowo. [...] W kilka minut po nas nadjechał ppłk dypl. Chłusewicz i mjr Sokołowski. [...] Płk dypl. Chłusewicz zapytany o ś.p. generała - oświadczył, że [generał - A.J.] został zbudzony, i że nie zna przyczyny jego nieobecności, bo pierwotny punkt przekroczenia granicy pod Kaletami został wieczorem dnia 21.IX zmieniony na Giby. Granicę przekroczono dnia 22.IX o godz. 9.03. Dopiero w drodze do Olity dowiedziałem się, że ś.p. generał wyjechał z Teolina nie na Giby, lecz na Kalety..."18.

${ }^{15}$ Opinia gen. J. Rómmla o płk. Jarosławie Okulicz-Kozarynie, 18 X 1938, IJPNY, AJP, sygn. 701/1/120, www.pilsudski.org/archiwa/ (dostęp: 4 VI 2018).

${ }^{16}$ Opinia płk. Józefa Werobeja, dowódcy PD 13 DP o płk. dypl. Benedykcie Chłusewiczu za rok 1935, Centralne Archiwum Wojskowe - Wojskowe Biuro Historyczne w Warszawie [dalej: CAW-WBH], Płk dypl. Benedykt Chłusewicz, AP I.481.C.1238, karty bez paginacji.

17 Opinia płk. dypl. Aleksandra Myszkowskiego o płk. dypl. Benedykcie Chłusewiczu za rok 1935, ibidem.

${ }_{18}$ Zbiory Przemysława Wilczyńskiego, bratanka gen. bryg. J. Olszyny-Wilczyńskiego, Wiadomości zebrane z ostatnich dni życia ś.p. gen. bryg. Józefa Olszyny-Wilczyńskiego, D-cy OK Nr III, Relacja mjr. Karola Miałkowskiego, Kalwaria Suwalska, 22 IV 1940, rkps, s. 7-8. 
Decyzja płk. B. Chłusewicza, daleka od zwykłej ludzkiej przyzwoitości, niekoniecznie wynikała z tchórzostwa. Najwyraźniej była wynikiem chłodnej kalkulacji, w której nie mieściła się śmierć w nierównej walce czy niewola. Zdołał on bezpiecznie opuścić Polskę i dotrzeć do Francji. W szeregach Samodzielnej Brygady Strzelców Podhalańskich walczył pod Narwikiem. Przeżył wojnę, pozostał na emigracji, zmarł w $1951 \mathrm{r}$.

Ze spokojem i opanowaniem odnosił się do zmieniającej się sytuacji również płk dypl. Bohdan Hulewicz. Przez lata zdystansowany do otoczenia, był bardziej intelektualistą i wykonawcą niż wojowniczym oficerem. Chociaż w swych działaniach wykazywał dużą pracowitość i sumienność, to jednak bez szczególnej inicjatywy. Jak zauważył gen. bryg. Wiktor Thommé: „Jako wykonawca solidny i nie wyjdzie z postawionych mu ram"19. Pułkownik B. Hulewicz zachowywał spokój i opanowanie także w momencie przekraczania granicy w Kutach. Po latach przyznał: „,...] Byłem wściekły na samo przejście przez granicę Polski i opuszczenie kraju. [...] Jeszcze nie zdawałam sobie sprawy z tego, że dla mnie wojna jest skończona, nie przeczuwałem, że już w niej udziału nie wezmę, ale zdawałem sobie sprawę ze strasznej klęski poniesionej przez armię polską i cały kraj" 20 .

Szef sztabu Obszaru Warownego „Wilno”, mjr A. Romiszowski, nie składał żadnych deklaracji w sprawie obrony Wilna. Brakuje w każdym razie wiarygodnych przekazów na ten temat. Wykonywał rozkazy dotyczące ewakuacji i w końcu zdecydował o opuszczeniu walczącego kraju. Nie zamierzał jednak spędzić całej wojny w niewoli, o czym zameldował dowódcy Obszaru Warownego „Wilno”. Granicę przekroczył o świcie 20 września w miejscowości Turmonty, w cywilnym ubraniu, z zamiarem przedostania się do Rygi. Został ujęty przez patrol łotewski i osadzony w obozie, z którego uciekł. Następnie przez Sztokholm i Londyn dotarł do Paryża ${ }^{21}$.

Determinacją i konsekwencją wykazał się mjr Benedykt Serafin. Nie był wprawdzie oficerem Obszaru Warownego „Grodno”, ale zaangażowany był w sprawę obrony Grodna. Jego postawa kontrastuje z poglądami dowódców, od których zależały losy miasta w tym czasie. Była także bliska oczekiwaniom wszystkich tych, którzy walkę uważali za absolutny obowiązek i konieczność. Major B. Serafin uważany jest za faktycznego przywódcę obrońców Grodna, którym towarzyszył niemal do końca. On także otrzymał rozkaz opuszczenia miasta, ale go nie wykonał. Zamiast ewakuacji przystąpił do realizacji planów, uzgodnionych wcześniej z gen. J. Olszyną-Wilczyńskim. Zdecydowany zwolennik stawienia oporu otrzymał zapewnienie, że będzie miał wyłączny wpływ na wszystkie sprawy z tym

${ }^{19}$ Opinia gen. bryg. Wiktora Thommé z 18 IV 1938 r., CAW-WBH, Płk. dypl. Bohdan Hulewicz, AP, 1769/89/1798, karty bez paginacji.

${ }^{20}$ B. Hulewicz, Wielkie wczoraj w matym kręgu, Warszawa 1973, s. 211.

${ }^{21}$ Relacja szefa sztabu Dowództwa Obszaru Warownego Wilno..., [w:] Wrzesień 1939 na Kresach..., s. 152. 
związane. O wspomnianym już batalionie wartowniczym $\mathrm{nr}$ 31, sformowanym w sierpniu 1939 r., mówił m.in.: ,[...] wcielałem starszych ludzi, rozmaitych narodowości, mniej wyszkolonych itd. Zadanie tego Baonu było, po opuszczeniu Oddziałów liniowych objąć nadzór nad majątkiem wojskowym m. Grodna"22. Pierwotnym celem mjr. B. Serafina była obrona Grodna przed Niemcami. Gdy 17 września wojskie sowieckie przekroczyły granicę Polski, myślał o zaprzestaniu dalszej walki, uzasadniając tę decyzję następująco: „Początkowo byłem w rozterce czy walkę kontynuować, gdyż były pogłoski, że wojska sowieckie idą nam na pomoc, jednak dowiedziałem się, że zbombardowali Głębokie postanowiłem użyć Oddziały przeznaczone do walki z Niemcami, przeciw siłom sowieckim"23.

Nawet ci, którzy decydowali się na walkę, zmieniali swoje wcześniejsze postanowienia pod wpływem pogarszającej się sytuacji. Należał do nich m.in. gen. dyw. w st. spocz. Wacław Przeździecki. W 1935 r. Inspektor Armii gen. dyw. inż. Leon Berbecki pisał o nim następująco: „Charakter wyrobiony, lecz b. nerwowy. [...] Bardzo duży talent taktyczny i ambicja pracy. Dowódca ofensywny i brawurowy"24. Tuż po wkroczeniu Armii Czerwonej gen. J. Olszyna-Wilczyński powołał go na stanowisko dowódcy Zgrupowania „Wołkowysk”, które pierwsze kroki skierowało do Wilna. Na wiadomość, że miasto nie będzie bronione, gen. W. Przeździecki nakazał marsz do Grodna, do którego wkroczył 20 września, obejmując dowództwo, także nad siłami mjr. B. Serafina. Nie zważając na beznadziejne położenie miasta i jego mieszkańców oraz wbrew racjonalnej ocenie sytuacji, podjął próbę obrony. Generał zarządził wykonanie pułapek przeciwczołgowych, polecił zabarykadować mosty na Niemnie, a także zorganizował wypiek chleba i zaopatrzenie wojska. Z pomocą patroli policji zaprowadził w mieście porządek ${ }^{25}$. Były to jednak chwilowe działania, które nie zabezpieczyły miasta. W godzinach popołudniowych 21 września do Grodna wkroczyły pierwsze czołgi sowieckie. Upadek miasta i postawę jego obrońców gen. W. Przeździecki skomentował dosadnie: „Walka o Grodno była ukończona, a jej nagły charakter i wycofywanie się bez rozkazu i łączności, a często bez nacisku npla, świadczyło o całkowitej bezwartości tej zbieraniny piechoty, która była w Grodnie"26.

Generał W. Przeździecki nie szczędził po wojnie słów krytyki gen. bryg. Józefowi Olszynie-Wilczyńskiemu, obarczając go winą za odstąpienie od obrony Grodna i Wilna. Sam natomiast kierując się do Grodna, przekonany o słuszności swej decyzji, szybko musiał się z niej wycofać. Wraz z oddziałami Brygady

${ }^{22}$ Kwestionariusz mjr. Benedykta Władysława Serafina, IPMS, sygn. B.I.70/4, s. 1.

${ }^{23}$ Ibidem, s. 2.

${ }^{24}$ Opinia Inspektora Armii gen. dyw. Leona Berbeckiego o gen. bryg. Wacławie Przeździeckim za rok 1935, CAW-WBH, Biuro Personalne MSWojsk, sygn. I.300.18.213., karty bez paginacji.

${ }^{25}$ Sprawozdanie gen. bryg. Wacława Przeździeckiego, dowódcy Obrony Rejonu Wołkowysk, nastepnie Grupy Operacyjnej, [w:] R. Szawłowski, Wojna polsko-sowiecka 1939, t. II (Dokumenty), Warszawa 1997, s. 42.

${ }^{26}$ Ibidem, s. 45. 
Kawalerii Rezerwowej „Wołkowysk” (główna siła Zgrupowania „Wołkowysk”) opuścił miasto 22 września we wczesnych godzinach porannych, nie informując o swej decyzji mjr. B. Serafina. Krytykując innych dowódców, oceniając negatywnie ich postawy w obliczu zagrożenia, gen. W. Przeździecki opuścił Grodno i pozostawił mieszkańców na pastwę wkraczających wojsk sowieckich. Jak wielu innych, także i on przekroczył granicę litewską, ale w swoim mniemaniu w poczuciu dobrze spełnionego obowiązku wobec zagrożonej ojczyzny.

Odejście gen. W. Przeździeckiego i wkroczenie do miasta wojsk sowieckich zmusiło do opuszczenia miasta także mjr. B. Serafina. Po ośmiogodzinnej walce, wraz z oddziałem liczącym około 600 żołnierzy, wycofał się z Grodna w kierunku Puszczy Augustowskiej. Tam walczył jeszcze do 23 września. Tego samego dnia w godzinach wieczornych przeszedł przez granicę litewską i został internowany w Olicie ${ }^{27}$.

Najazd sowiecki pogłębiał postępujący chaos organizacyjny, a w konsekwencji przybliżał moment ostatecznej klęski. Armia Czerwona wkroczyła do Wilna 19 września 1939 r., Grodno zostało zajęte 22 września. Rozpoczęła się krwawa rozprawa z obrońcami. Był to także czas opinii i ocen, emocjonalnych i zupełnie skrajnych, ale niedających żadnych odpowiedzi na nurtujące pytania o sens i perspektywy walki. Działania zarówno płk. J. Okulicz-Kozaryna, jak i ppłk. T. Podwysockiego zostały przez niektórych ocenione jednoznacznie. Swoje oburzenie na ich temat wyraził wspomniany już płk. K. Rybicki, który po latach pisał następująco: „Wilno zostało oddane haniebnie, zgodnie z rozkazem dcy III. Korpusu. Sytuacja oficerów dowodzących obroną [...] jest godna pożałowania, co im było kazane z góry, to wykonali” ${ }^{\prime 2}$. Według opinii gen. bryg. W. Przeździeckiego w tej trudnej sytuacji zawiedli przede wszystkim dowódcy, odznaczyli się natomiast podwładni. W pozostawionej relacji nie oszczędził tych pierwszych, którzy według niego zachowywali się ,,[...] poniżej wymaganego minimum żołnierskiej postawy i odwagi" ${ }^{29}$. Oceniając natomiast skuteczność działania swojego zgrupowania, generał stwierdził m.in.: ,[...] chęć walki i męstwo były silnie zaznaczone i wykazywane przez szeregowych. Natomiast w jednostkach i grupkach piechoty, marszówek wartowniczych itp. oficerowie całkiem zwodzili. Niejednokrotnie żołnierze nie mogli wykonać swej chęci do walki, bo opuszczeni przez d-ców, bezradni, nie wiedzieli co czynić. [...] haniebnie zachowały się władze administracyjne i policja. Pierwszy zamęt i panika podnoszone były przez organa administracji. Urzędnicy województwa, starostw itp. dbali tylko, by swe drogocenne osoby ratować $\mathrm{z}$ opresji, a policja mundurowa i rezerwowa włączona w działania grupy nigdy nie wykonała poleconego im zadania. Zamęt i uciecz-

${ }^{27}$ Kwestionariusz mjr. Benedykta Władysława Serafina, IPMS, sygn. B.I.70/4, s. 2. Vide też P. Ko śc iń s k i, Obrońca Grodna. Zapomniany bohater, Warszawa 2017.

${ }^{28}$ Relacja pułkownika Kazimierza Rybickiego..., [w:] Wrzesień 1939 na Kresach..., s. 170.

${ }^{29}$ Sprawozdanie gen. bryg. Wacława Przeździeckiego..., [w:] R. S zawłow s k i, op. cit., s. 45. 
ka to cała czynność policji. Na tym smutnym tle wykwitało jasnymi błyskami bohaterstwo poszczególnych oficerów, szeregowych i ochotników"30.

Z dramatycznego rozwoju wydarzeń w Grodnie i w Wilnie wynikało wiele decyzji, nie zawsze racjonalnych, odpowiedzialnych czy mających szansę powodzenia. Żadna z nich, podjęta pod wpływem emocji czy nawet w wyniku realnej oceny sytuacji, nie była dobrym wyjściem. Walczyć czy z walki zrezygnować i ewakuować wojsko, które może przydać się jeszcze na innym froncie; poddać się czy zginąć w nierównej walce - to pytania, które towarzyszyły uczestnikom tamtych wydarzeń, które do dziś nie doczekały się jednoznacznych odpowiedzi. Towarzyszą im natomiast skrajne opinie, jak ta przytoczona przez grodzieńskiego harcerza, obrońcę miasta, który przebył drogę w kierunku granicy litewskiej. W swych wspomnieniach napisał m.in.: „Szczególnie przygnębiające wrażenie sprawiały trupy wyższych oficerów wojska i policji, najspokojniej siedzace pod potężnymi chojarami sosnowymi. Nie mogli, nie potrafili przeżyć klęski, odebrali sobie życie, o czym świadczyły visy w zastygniętych dłoniach. Mieli poczucie żołnierskiego honoru, toteż nie zdołali przeżyć klęski, którą uważali za plamę na swoim żołnierskim mundurze. Podchorąży, dowódca naszego plutonu, tak ten widok skwitował: »To jest chwalebne tchórzostwo, Polski nie można przekreślić po jednej klęsce, należy ją wywalczyć ponownie. Polsce obecnie są potrzebni - jak nigdy dotychczas - żywi żołnierze, a nie tchórze strzelający sobie w łeb«"31.

Samobójcza śmierć niekoniecznie musiała być wynikiem tchórzostwa. Bezradność, załamanie psychiczne czy uczucie zwykłej, ludzkiej rozpaczy dla wielu oficerów były wystarczającym powodem, by odebrać sobie życie. Takie rozwiązanie stało się udziałem m.in. ppłk. Aleksandra Alexandrowicza, szefa fortyfikacji Obszaru Warownego „Wilno”. Zmagający się od dłuższego czasu z depresją oficer ten zastrzelił się 16 września, w czasie inspekcji robót fortyfikacyjnych w Zwierzyńcu - dzielnicy Wilna ${ }^{32}$.

Podobne i równie tragiczne zdarzenia miały miejsce w Zawiasach ${ }^{33}$, głównym kierunku ewakuacji z Wilna na Litwę. Wielu oficerów, którzy się tam wówczas znaleźli, zgodnie relacjonowało atmosferę i wypadki, jakie się wtedy rozegrały. Określali je jako dantejskie lub tragiczne, gdzie płacz mieszał się ze śpiewem patriotycznych pieśni, a przekleństwom i obelgom wobec przekraczających granicę oficerów i podoficerów towarzyszyło niejednokrotnie zrywanie dystynkcji. Niszczona była także broń ${ }^{34}$. Wielu potwierdzało przypadki samobójstw. Jak

${ }^{30}$ Ibidem, s. 49.

${ }^{31}$ J. S i emińs ki, Walczące Grodno. Wspomnienia harcerza, Białystok 1990, s. 47.

32 S. Ku charski, Obszar Warowny ,Wilno”, Warszawa 2015, s. 56; R. Ry b ka, K. S te pa n, Rocznik oficerski 1939, Kraków 2006, s. 530.

${ }^{33}$ Zawiasy - wieś w gminie Troki w województwie wileńskim. Mieściła się tam stacja kolejowa, punkt kontroli granicznej oraz strażnica KOP „Zawiasy”, która znajdowała się w składzie 2 kompanii KOP „Rykonty” 22 batalionu granicznego 6 Brygady KOP.

${ }^{34}$ Relacja pułkownika Kazimierza Rybickiego..., [w:] Wrzesień 1939 na Kresach..., s. 162. 
wspominał ppor. Witold Barancewicz: „,...] W Zawiasach zastałem sytuację wprost tragiczną. Część żołnierzy i dużo samochodów cywilnych przekroczyło już granicę litewską. Obok strażnicy KOP jakiś oddział śpiewał: »Nie rzucim ziemi...« Kilku oficerów popełniło samobójstwo"35.

Wydarzenia, które rozegrały się w Grodnie i w Wilnie we wrześniu 1939 r., nasuwają szereg pytań o przyczyny klęski, ale też o tak zróżnicowane postawy ludzi. Warto zastanowić się nad tym, czy niewykonanie rozkazu o ewakuacji i tym samym o odstąpieniu od obrony miasta było sprawa naganną? Czy należało wówczas ratować życie własne i innych wbrew oczekiwaniom otoczenia, narażając się na zarzuty tchórzostwa, zdrady, okrycia hańbą nazwiska i munduru? A może jednak należało poświęcić życie swoje i podwładnych w imię honoru oficerskiego i całej armii? I w końcu: dlaczego żaden z dowódców, mających na pewno świadomość nieuchronnej klęski, nie stanął na czele broniących miasta mieszkańców i nie podzielił ich losu w imię szczytnych ideałów, głoszonych już po upadku Grodna, będąc z dala od tragicznych konsekwencji, jakie musieli ponieść obrońcy. Jeszcze w trakcie trwania wojny, jak i w powojennej historiografii pojawiło się sporo krytycznych ocen pod adresem polskich dowódców, których obarcza się odpowiedzialnością za odstąpienie od obrony Wilna i Grodna. Z ocen tych wynika jednak gorzka prawda, że nawet najbardziej bohaterska postawa i dowódców, i zwykłych ludzi nie zdołała wówczas odwrócić biegu zdarzeń na wschodnich ziemiach Drugiej Rzeczpospolitej, gdzie podobnie jak na całym terytorium Polski we wrześniu 1939 r. toczono walkę głównie o honor. I z pewnością taki właśnie był cel zwolenników podjęcia obrony Grodna i Wilna. Polska, skupiona na wojnie z Niemcami, została zaskoczona sowieckim najazdem. Całą sytuację pogarszał jeszcze słynny rozkaz Naczelnego Wodza, który głosił, aby „[...] z bolszewikami nie walczyć, chyba w razie natarcia z ich strony albo próby rozbrojenia oddziałów. [...] Miasta, do których podejdą bolszewicy, powinny z nimi pertraktować w sprawie wyjścia z garnizonów do Węgier lub Rumunii”. Trudno wyobrazić sobie wykonanie tego rozkazu w obliczu sowieckiej agresji. Przewidywania Naczelnego Wodza co do możliwości pertraktacji z najeźdźcą rozminęly się z rzeczywistością, a oznacza to, że w praktyce stały się niewykonalne. Armia Czerwona, nierespektująca żadnych zasad ani konwencji o prowadzeniu wojny w sposób cywilizowany, nie dawała polskiemu wojsku szans na wypełnienie rozkazu marsz. Edwarda Rydza-Śmigłego. W tamtej sytuacji rozkazy stały się osobistymi decyzjami oficerów, wynikającymi z ich przekonań i poczucia obowiązku. Dla jednych śmierć w nierównej walce w imię honoru była symbolem nieugiętej postawy i trwania państwa polskiego. Dla innych - bezsensownym narażaniem życia żołnierzy w imię ideałów, które i tak nie mogły już powstrzymać klęski wojska i całego państwa.

${ }^{35}$ Relacja dowódcy 20 baterii artylerii przeciwlotniczej podporucznika Witolda Barancewicza, [w:] ibidem, s. 127. 
Dziś, po upływie wielu lat bardzo łatwo można ocenić tamtych ludzi, nadając im etykiety tchórza, zagubionego i nieudolnego dowódcy czy bohatera. Trudno zbadać motywy działania tych ludzi w sytuacji zagrożenia, w obliczu odpowiedzialności za innych, w obliczu śmierci. Na wiele zadanych pytań trudno też uzyskać odpowiedź. Pewne natomiast jest to, że wojna zmienia ludzi, zmienia ich stosunek do obowiązków i do otoczenia. Poddaje próbie ludzkie charaktery, często szlachetne i pełne ideałów, które w sytuacji krytycznej ustępują miejsca rezygnacji z dotychczasowych wartości za cenę ratowania życia lub wyzwolenia się z odpowiedzialności. Także postawy często irracjonalne, oceniane jako naganne, nie zawsze poddają się opiniom zgodnym z obowiązującymi i akceptowanymi normami. Nigdy nie dowiemy się, co kierowało ludźmi w tamtym momencie. Natomiast dylemat: walczyć czy odstąpić, nierozstrzygnięty, nadal będzie budził spory i dyskusje.

\section{Bibliografia}

\section{ŹRÓDEA ARCHIWALNE}

Centralne Archiwum Wojskowe - Wojskowe Biuro Historyczne w Warszawie [CAW-WBH]

Opinia płk. Józefa Werobeja, dowódcy PD 13 DP o płk. dypl. Benedykcie Chłusewiczu za rok 1935; Opinia płk. dypl. Aleksandra Myszkowskiego o płk. dypl. Benedykcie Chłusewiczu za rok 1935, Płk dypl. Benedykt Chłusewicz, AP I.481.C.1238.

Opinia gen. bryg. Wiktora Thommé z 18 kwietnia 1938 r., Płk. dypl. Bohdan Hulewicz, AP, 1769/89/1798.

Opinia Inspektora Armii gen. dyw. Leona Berbeckiego o gen. bryg. Wacławie Przeździeckim za rok 1935, Biuro Personalne MSWojsk, sygn. I.300.18.213.

Instytut Polski i Muzeum im. Gen. Sikorskiego w Londynie [IPMS]

Sprawozdanie mjr. Karola Miałkowskiego z prac organizacyjnych „Grupy Grodno” stworzonej z rozkazu Naczelnego Wodza 1 IX 1939 r., sygn.B.I.70.D.

Kwestionariusz mjr. Benedykta Władysława Serafina, sygn. B.I.70/4.

Instytut Józefa Piłsudskiego w Nowym Jorku [IJPNY]

Opinia gen. J. Rómmla o płk. Jarosławie Okulicz-Kozarynie, 18 X 1938 r., Archiwum Józefa Piłsudskiego, sygn. 701/1/120, www.pilsudski.org/archiwa/ (dostęp: 4 VI 2018).

Opinia inspektora armii gen. M. Norwid-Neugebauera o ppłk. T. Podwysockim, 18 III 1936, Archiwum Józefa Piłsudskiego, sygn. 701/1/120, www. pilsudski.org./archiwa/ (dostęp: 4 VI 2018).

Zbiory Przemysława Wilczyńskiego, bratanka gen. bryg. J. Olszyny-Wilczyńskiego

Wiadomości zebrane z ostatnich dni życia ś.p. gen. bryg. Józefa Olszyny-Wilczyńskiego, D-cy OK Nr III, Relacja mjr. Karola Miałkowskiego, Kalwaria Suwalska, 22 IV 1940, rkps, s. 7-8. 


\section{ŹRÓDEA DRUKOWANE}

Hulewicz B., Wielkie wczoraj w małym kręgu, Warszawa 1973.

Polskie Sity Zbrojne w drugiej wojnie światowej, t. I (Kampania wrześniowa 1939), cz. 3 (Przebieg działań od 9 do 14 września), Londyn 1959.

Relacja dowódcy 20 baterii artylerii przeciwlotniczej podporucznika Witolda Barancewicza, [w:] Wrzesień 1939 na Kresach w relacjach, wybór i oprac. C.K. Grzelak, Warszawa 1999, s. $125-128$.

Relacja podpułkownika piechoty Kazimierza Kardaszewicza, dowódcy pułku KOP „Wilno” (jednocześnie dowódcy granicznego odcinka litewskiego), [w:] Wrzesień 1939 na Kresach w relacjach, wybór i oprac. C.K. Grzelak, Warszawa 1999, s. 82-94.

Relacja pułkownika Kazimierza Rybickiego z wydarzeń w Wilnie i na pograniczu polsko-litewskim, [w:] Wrzesień 1939 na Kresach w relacjach, wybór i oprac. C.K. Grzelak, Warszawa 1999, s. $152-170$.

Relacja szefa sztabu Dowództwa Obszaru Warownego Wilno, majora dyplomowanego Aleksandra Mariana Romiszowskiego z wydarzeń w Wilnie, Paryż 12 października 1939 r., [w:] Wrzesień 1939 na Kresach relacjach, wybór i oprac. C.K. Grzelak, Warszawa 1999, s. 145-152.

Rybka R., Stepan K., Rocznik oficerski 1939, Kraków 2006.

Siemiński J., Walczace Grodno. Wspomnienia harcerza, Białystok 1990.

Sprawozdanie gen. bryg. Wacława Przeździeckiego, dowódcy Obrony Rejonu Wołkowysk, następnie Grupy Operacyjnej, [w:] R. Szawłowski, Wojna polsko-sowiecka 1939, t. II (Dokumenty), Warszawa 1997, s. 41-49.

\section{Opracowania}

Grzelak C., Kresy w czerwieni. Agresja Zwiazku Radzieckiego na Polskę w 1939 roku, Warszawa 2001. Grzelak C., Wilno-Grodno-Kodziowce 1939, Warszawa 2002.

Kościński P., Obrońca Grodna. Zapomniany bohater, Warszawa 2017.

Kucharski S., Obszar Warowny „Wilno”, Warszawa 2015.

Wodzyński A., 1 Dywizja Piechoty Legionów, Warszawa 2016.

Wróblewski J., Armia „Prusy”1939, Warszawa 1986.

AgniesZKa JęDRZEJEWSKa

\section{To fight or not to fight? Grodno and Wilno Fortified Areas' officers and their attitudes and dilemmas in September 1939}

In August 1939 all main Polish military units from Grodno and Wilno garrisons were mobilized to fight against German army and were send to the west frontline. This way, both cities were left without regular army's units, remained defenceless against Soviet aggression. It was impossible to stand up the fight in this situation. The only way for the reserve units, which have stayed, was evacuation from Poland to Lithuania. Many officers of Fortified Areas Grodno and Wilno had to make a difficult decision: to stay and fight or to leave Poland and go to Lithuania. This dilemma, one among many others, had influence on their attitudes and decisions during this tragic time.

Keywords: September 1939, Fortified Area, Grodno, Wilno, Polish Army, evacuation. 